\title{
FACTORS INFLUENCING GROUP VIABILITY AMONG CASSAVA PROCESSOR GROUPS OF THE ROOT AND TUBER EXPANSION PROGRAMME (RTEP) IN OYO STATE, NIGERIA
}

BR Olajide* and LA Oyebode

Department of Agricultural Extension and Rural Development, University of Ibadan, Ibadan, Nigeria

Accepted: $25^{\text {th }}$ July 2014

\begin{abstract}
Many agricultural development interventions such as Root and Tuber Expansion Programme (RTEP) have used groups as veritable tool for accelerating contacts with project targets. However, continued existence and viability of such groups remains a challenge in the post intervention era. This paper examines factors influencing group viability among cassava processor groups of RTEP in Oyo State, Nigeria. Purposive sampling technique was used to select 116 respondents who were registered members of cassava processor groups as they have in place viable groups for the use of this study. Information was obtained on respondents' socioeconomic characteristics, the extent and frequency of participation in group activities, constraints to participation, and compliance of their groups to set guidelines. Data was analysed using both descriptive and inferential statistics at $p=0.05$. Results show that most $(44.0 \%)$ of the respondents were between 41 and 50 years with mean household size of 6 persons. More than half $(56.0 \%)$ attended group meeting while a reasonable proportion $(\mathbf{4 9 . 1 \% )}$ made useful contribution during group meetings and paid dues $(\mathbf{4 4 . 0} \%)$ while $87.1 \%$ paid such dues frequently. Respondents were however constrained by high cost of transportation (58.6\%) and raw materials for processing (50.9\%) and inadequate finance $(49.1 \%)$ as well as poor market linkage (45.7\%). Total compliance was recorded for record keeping $(63.8 \%)$ and attendance at meetings $(62.1 \%)$. Group viability was predicted by respondents' household size $(\beta=0.142)$, frequency of participation in group activities $(\beta=0.142)$ and group constraints $(\beta=-0.342)$. More infrastructures like road and input supply as well as soft loans to members of the group will further enhance group viability.
\end{abstract}

Key words: Group viability, Participation, Compliance, Root and tuber expansion programme

\section{INTRODUCTION AND PROBLEM STATEMENT}

Nigeria is basically an agrarian country, with about $65 \%$ of the population earning their living from agriculture. The level of adoption of technology in Nigeria's agriculture is relatively low because technologies developed through research and development activities are not reaching the peasant farmers. This situation calls for a virile extension system that will link the farmers with the researchers effectively. However, the regular contact required for achieving this is highly impaired by the very low Extension Agents (EA) to farm families' ratio all over the states across the country. The ratio as at year 2000 ranged between one extension agent to 1,500 in Niger state and 1,800 in Lagos state with an overall average of 1:1, 968 as against the ratio of 1 to 500 recommended by the Food and Agricultural Organization (FAO) of the United Nations (Okoye and Ihi- modu, 2004). The logistic difficulty confronting extension agents to reach and maintain regular contacts with farm families is what the use of groups for agricultural extension service delivery in Nigeria seeks to overcome.

The age-old practice of extension - farmer contact on one -on - one basis, though very effective, is expensive and unsustainable means of reaching farmers with agricultural technology. New methods emphasize the passing on of agricultural technology to farmers in organized groups (farmer groups). A farmer group is a collection of farmers interacting with one another towards achieving a common goal. Usually, the interaction between the members of the group is more than with those outside the group. Membership of a group varies and it is advantageous to have a small number of people in a group. A group size of between 20 and 30 is ideal and manageable in order to provide a

\footnotetext{
*Corresponding author: r.olajide@gmail.com
} 
face-to face interaction, better communication and free flow of information.

The farmer -group approach plays a valuable role in policy advocacy and in realizing economies of scale. One major benefit of the group is that farmers support each other to learn about and adopt innovations. Thus, an extension farmer-to-farmers system is amplified (FAO, 2001). Rather than simply be agents for technologies imposed from outside, the extension agents then play the role of catalysts, mobilizing farmers to experiment on an identified need and solution as well as recognizing local innovations (Stringfellow, Coulster, Lucy, Mekone and Hussam, 1997). Experienced farmers thus become the best discussion partners for other farmers. A farmers' network of communication then operates in a sustainable basis since it is perpetuated continually for generations.

The advantages of using groups such as farmer's cooperatives and associations according to Ladele (1995) and Conroy (2003) lies in coverage of farming community leading to improved dissemination of extension messages and agricultural innovations among farmers. Dealing with groups for extension work also confers advantage of saving time and reduction in cost per head, it allows for participation of more people, self improvement due to skill acquisition and educational opportunities offered through adult education and literacy programmes. It equally provides supportive services to complement the education function of extension.

Be this as it may, most intervention programmes only had group formation and management as appendages and not the main focus of the programme. The need for beneficiary involvement in agricultural programmes has been stressed by several authors (Ekong, 2007; Chamala and Shingi, 1997; Dannson et al, 2004; Srivastava, 2007). The encouraging attributes of the farmers' organization makes them one of the main target group in the implementation of the Root and Tuber Expansion Programme (RTEP). At the inception of RTEP, twelve cassava processor groups were formed in Oyo state and they all participated in the first phase of the programme between August 2001 and March 2010. However, it is worrisome to note that out of the twelve processor groups adopted under the first phase of the programme, only six survived beyond this first phase and are been considered for the sustainable phase of the programme (RTEP II). Owing to the huge financial, material and human resources sunk into the programme, it is imperative that current groups being considered for RTEP II are nurtured for sustainability and enhancement of the objectives of RTEP. It is an established fact that many agricultural development interventions such as Root and Tuber Expansion Programme (RTEP) have used groups as veritable tool for accelerating contacts with project targets. However, continued existence and viability of such groups remains a challenge in the post intervention era. It is against this background that this study investigated the six surviving groups to ascertain their viability beyond RTEP and also take advantage of subsequent programmes. This study was conceived to achieve the following specific objectives:

1. To examine the socio-economic characteristics of members of cassava processor groups under RTEP in the study area.

2. To determine the extent and frequency of participation in group activities by members of cassava processor groups under RTEP in the study area.

3. To identify constraints encountered by members of cassava processor groups under RTEP in the study area.

4. To determine compliance with RTEP set guidelines.

5. To ascertain factors influencing group viability among cassava processor groups of RTEP in Oyo State

\section{METHODOLOGY}

The study was carried out in Oyo State, which is one of the 36 states in Nigeria. The state is an inland state in southwestern, Nigeria which has its capital as Ibadan. There are 33 local government areas in the state. The population 
of Oyo State according to the 2006 national population census report stood at 5,591,589 (NPC 2007). Population of the study comprised all members of cassava processor groups under RTEP in Oyo State. There are six RTEP groups in Oyo state spread across three out of the four Agricultural Development Programme (ADP) zones. Members of cassava processor groups that are participating in RTEP in the state were purposively sampled in this study as they constitute the main target of the study and also have in place viable groups for the use of this study. All the 116 registered members of the groups were used for this study. Variables measured included group members' socio-economic characteristics, extent and frequency of participation, perceived problems of the cassava processors' groups, group compliance and factors influencing group viability. Extent and frequency of participation were measured by presenting a list of regular group activities to the respondents. Respondents were then asked to indicate extent of participation in group activities and on a four-point -scale of not active, moderately active, active and very active. For frequency of participation, respondents were asked to indicate how frequently they participate in group activities on a threepoint scale of not frequent, frequent and very frequent. For constraints, a list of possible constraint peculiar to the processors' group was presented and respondents were asked to indicate level of severity of each constraint as it affects their group activities. This was measured as severe, mild and not a constraint. Compliance was determined on a two-point scale of total and partial compliance to guideline moderating conduct of the activities of the cassava processors' groups. Data was collected using interview schedule and was analyzed using descriptive (frequency, percentages and means) and inferential (regression) statistics at $p=0.05$. Regression was used to isolate those variables that are germane to group viability.

\section{RESULTS AND DISCUSSION}

\section{Respondents' personal characteristics}

Table 1 indicates that most $(44.0 \%)$ of the respondents fell between the age range of 4150 years, $37.9 \%$ were 50 years and above while $13.8 \%$ were between $36-40$ years. It can be inferred that majority of the sampled respondents are in their economically active age. It should be noted that age is an important factor for consideration in agricultural activities; age determines the level of involvement in farming and other activities alike (Zhang and Flick, 2001). Available statistics in Table 1 further reveals that more women $(64.7 \%)$ than men $(35.3 \%)$ were involved in processing. This agrees with FAO (2001) that women are more involved in off-farm activities than men while Afolani and Ajani (1995) asserts that the cassava post harvest system have assigned gender roles. Majority $(66.4 \%)$ of the respondents had a household size of 6 to 8 with a mean of 5.96. This implies that they have a fairly large family size which could probably serve as an insurance against short fall in labour supply. Household size has a great role to play in family labour provision in the agricultural sector (Sule, Ogunwale and

Table 1: Socio-economic characteristics of respondents $(n=116)$

\begin{tabular}{llll}
\hline Variables & Frequency & Percentage & Mean \\
\hline Age & 5 & 4.3 & \\
$31-35$ & 16 & 13.8 & \\
$36-40$ & 51 & 44.0 & \\
$41-50$ & 44 & 37.9 & 45.6 \\
50 and Above & 116 & 100.0 & \\
Total & & & \\
Sex & 41 & 35.3 & \\
Male & 75 & 64.7 & \\
Female & 116 & 100.0 & \\
Total & & & \\
House hold size & 32 & 27.6 & \\
$1-5$ & 77 & 66.4 & \\
6-8 & 7 & 6.0 & \\
9-12 & & & \\
Educational Attainment & 41 & 35.3 & \\
No formal education & 2 & 1.7 & \\
Quranic education & 5 & 4.3 & \\
Adult education & 58.0 & \\
Primary education & 44 & 9.5 & \\
Secondary education & 11 & 11.2 \\
Tertiary education & 13 & 100.0 \\
Total & 116 &
\end{tabular}


Atala 2002). The table further reveals that more than one third $(38.0 \%)$ had primary education, $35.3 \%$ had no formal education and $11.2 \%$ had one form of tertiary education. This population can be said to be comparatively literate. Recent development with participants in agricultural intervention programmes like Fadama and RTEP is that quite a reasonable proportion of members of users groups have some level of educational attainment.

\section{Extent of participation of respondents in group activities}

Table 2 presents data on extent and frequency of respondents' participation in group activities. Available statistics in Table 2 reveals that majority $(64.7 \%)$ of the respondents actively participated in processing activity, more than half $(56.0 \%)$ attended group meeting while quite a reasonable proportion $(49.1 \%)$ made useful contribution during group meetings and paid group dues $(44.0 \%)$. These findings suggest that that the respondents are more active in processing activities which was the major activity of the group. This finding corroborates RTEP report (2010) that having embraced RTEP and invested over 700 million Naira in the establishment of improved cassava processing sheds and centers, 211 of which were fully operational, it is unlikely that programme beneficiaries would want to see their investments go down the drain, hence their active participation in processing activities. More than one third of members of the RTEP groups were equally active in activities like payment of dues (34.5\%) and active contribution during group meetings
$(33.6 \%)$. On a general note, it can be concluded that core activities of the group attracted reasonable participation to have nurtured the groups beyond the first phase of the intervention programme going to the sustainability phase.

\section{Respondents' frequency of participation in group activities}

Information in Table 2 further reveals the frequency of participation in group activities by the respondents. It shows how often RTEP group members are engage in group activities. The frequency of participation of most RTEP group members in group activities was high as up to four members out of every five members frequently participated in group activities. This was the picture for involvement in processing activities (88.0\%), payment of group dues $(87.1 \%)$, contribution during group meetings $(86.8 \%)$ and attendance of capacity building workshop $(77.6 \%)$. This trend possibly accounted for the survival of these groups beyond the first phase.

\section{Constraints encountered during RTEP}

Available statistics in Table 3 reveal that high cost of transportation (58.6\%), high cost of raw materials for processing $(50.9 \%)$, inadequate finance $(49.1 \%)$, inadequate infrastructure at processing sites $(46.6 \%)$ and poor market linkage $(45.7 \%)$ were severe constraints encountered during RTEP. This finding is in tandem with Dipeolu et al (2003) and Onyenweaku and Nwaru (2005) that enhancing access to finance, business skills and appropriate technologies, ensuring quality of products and

Tables 2: Distribution of respondents according to their extent and frequency of participation in group activities

\begin{tabular}{|c|c|c|c|c|c|c|c|}
\hline \multirow[t]{2}{*}{ Activities } & \multicolumn{4}{|c|}{ Extent of participation } & \multicolumn{3}{|c|}{ Frequency of participation } \\
\hline & $\begin{array}{l}\mathrm{N} \text { o t } \\
\text { active }\end{array}$ & $\begin{array}{l}\text { Moderately } \\
\text { active }\end{array}$ & Active & $\begin{array}{l}\mathrm{V} \text { e r y } \\
\text { active }\end{array}$ & $\begin{array}{l}\mathrm{N} o \mathrm{o} \\
\text { frequent }\end{array}$ & Frequent & $\begin{array}{cc}\begin{array}{l}\text { Very } \\
\text { quent }\end{array} & \text { Fre- } \\
\end{array}$ \\
\hline $\begin{array}{l}\text { Involvement in processing } \\
\text { activities }\end{array}$ & $4(3.4 \%)$ & $13(11.2 \%)$ & $24(20.7 \%)$ & $75(64.7 \%)$ & $14(12 \%)$ & $43(37.1 \%)$ & $59(50.9 \%)$ \\
\hline $\begin{array}{l}\text { Attendance in capacity } \\
\text { building workshop }\end{array}$ & $16(13.8 \%)$ & $14(12 . \%)$ & $35(30.2 \%)$ & $51(44.0 \%)$ & $26(22.4 \%)$ & $41(35.3 \%)$ & $49(42.3 \%$ \\
\hline Attending group meetings & $1(0.9 \%)$ & $21(18.1 \%)$ & $29(25.0 \%)$ & $65(56.0 \%)$ & $8(6.9 \%)$ & $50(43.1 \%)$ & $58(50.0 \%)$ \\
\hline $\begin{array}{l}\text { Contribution during group } \\
\text { meetings }\end{array}$ & $8(6.9 \%)$ & $12(10.2 \%)$ & $39(33.6 \%)$ & $57(49.1 \%)$ & $15(12.9 \%)$ & $39(33.4 \%)$ & $62(53.4 \%)$ \\
\hline Payment of group dues & $12(10.3 \%)$ & $13(11.2 \%)$ & $40(34.5 \%)$ & $51(44.0 \%)$ & $15(12.9 \%)$ & $39(33.7 \%)$ & $62(53.4 \%)$ \\
\hline
\end{tabular}


reliability of supply and integration of activities have been shown to have strong potential for sustainable value chains development (processing).

Table 3: Distribution of respondents based on perceived problems encountered during RTEP

\begin{tabular}{|c|c|c|c|c|c|c|c|}
\hline \multirow[t]{2}{*}{$\begin{array}{l}\mathbf{S} \\
/ \\
\mathbf{N}\end{array}$} & \multirow[t]{2}{*}{ Constraints } & \multicolumn{2}{|c|}{$\begin{array}{l}\text { Severe } \\
\text { Con- } \\
\text { straint }\end{array}$} & \multicolumn{2}{|c|}{$\begin{array}{l}\text { Mild } \\
\text { Con- } \\
\text { straint }\end{array}$} & \multicolumn{2}{|c|}{$\begin{array}{l}\text { Not a } \\
\text { Constraint }\end{array}$} \\
\hline & & $\mathrm{F}$ & $(\%)$ & $\mathrm{F}$ & $(\%)$ & $\mathrm{F}$ & $(\%)$ \\
\hline 1 & $\begin{array}{l}\text { High cost of } \\
\text { raw materials } \\
\text { for processing }\end{array}$ & 59 & 50.9 & 41 & 35.3 & 16 & 13.8 \\
\hline 2 & $\begin{array}{l}\text { No market } \\
\text { linkage }\end{array}$ & 53 & 45.7 & 46 & 39.7 & 17 & 14.6 \\
\hline 3 & $\begin{array}{l}\text { Inadequate } \\
\text { infrastructure } \\
\text { in processing } \\
\text { sites }\end{array}$ & 54 & 46.6 & 41 & 35.3 & 21 & 18.1 \\
\hline 4 & $\begin{array}{l}\text { Lack of pric- } \\
\text { ing policies }\end{array}$ & 44 & 37.9 & 42 & 36.2 & 30 & 25.9 \\
\hline 5 & $\begin{array}{l}\text { Lack of na- } \\
\text { tional standard } \\
\text { for cassava } \\
\text { products }\end{array}$ & 52 & 44.8 & 44 & 37.9 & 20 & 17.2 \\
\hline 6 & $\begin{array}{l}\text { High cost of } \\
\text { transportation }\end{array}$ & 68 & 58.6 & 37 & 31.9 & 11 & 9.5 \\
\hline 7 & $\begin{array}{l}\text { Poor access of } \\
\text { vehicles to } \\
\text { processing } \\
\text { sites }\end{array}$ & 50 & 43.1 & 51 & 44.0 & 15 & 12.9 \\
\hline 8 & $\begin{array}{l}\text { Inadequate } \\
\text { finance }\end{array}$ & 57 & 49.1 & 31 & 26.7 & 28 & 24.1 \\
\hline
\end{tabular}

\section{Compliance to RTEP Guidelines}

Information in Table 4 shows that of the four RTEP guidelines, total compliance by respondents was highest in their record keeping $(63.8 \%)$ and attendance at meetings $(62.1 \%)$. This can be adduced to the fact that the respondents' record is the first port of call by RTEP officers when they are on routine visit hence was properly rendered. Compliance with payment of dues $(50.9 \%)$ and attaining process flow specification $(50.0 \%)$ were only partially complied with. Attaining process flow specification means separation of wet processing area from dry processing area. Though, partially complied with, this can be attributed to the fact that the respondents are still used to their old method of cassava processing because of its ease. However, there is the need to comply totally because this will enhance the quality of processed products.

Table 4: Distribution of respondents extent of compliance with RTEP Set Guidelines

\begin{tabular}{|c|c|c|c|c|c|}
\hline \multirow{2}{*}{$\begin{array}{l}\mathbf{S} \\
/ \\
\mathbf{N}\end{array}$} & \multirow[t]{2}{*}{ Guidelines } & \multicolumn{2}{|c|}{$\begin{array}{l}\text { Partial com- } \\
\text { pliance }\end{array}$} & \multicolumn{2}{|c|}{$\begin{array}{l}\text { Total compli- } \\
\text { ance }\end{array}$} \\
\hline & & $\mathrm{F}$ & $\begin{array}{l}\mathrm{P} \\
(\%)\end{array}$ & $\mathrm{F}$ & $\begin{array}{c}\mathrm{P} \\
(\%)\end{array}$ \\
\hline 1 & Record keeping & 42 & 36.2 & 74 & 63.8 \\
\hline 2 & $\begin{array}{l}\text { Payment of dues and } \\
\text { contribution by } \\
\text { members }\end{array}$ & 57 & 49.1 & 59 & 50.9 \\
\hline 3 & $\begin{array}{l}\text { Attendance at meet- } \\
\text { ings which are held } \\
\text { fortnightly }\end{array}$ & 44 & 37.9 & 72 & 62.1 \\
\hline 4 & $\begin{array}{l}\text { Attaining process } \\
\text { flow specification } \\
\text { (separation of wet } \\
\text { processing area from } \\
\text { dry processing area) }\end{array}$ & 58 & 50 & 58 & 50 \\
\hline
\end{tabular}

\section{Regression analysis on group viability with the independent variables}

Available statistics in table 5 show that three variables; household size $(\beta=0.142)$, frequency of participation in group activities $(\beta=$ $0.142)$ and constraints $(\beta=-0.342)$, were the significant predictors of group viability. This implies that participants at the RTEP activities with less distraction from his or her household size, groups with lesser constraints and those that record frequent membership participation are more likely to be viable for the sustainable phase of the RTEP.

\section{CONCLUSION AND RECOMMENDA- TIONS}

On the premise of the available information, it is apparent that RTEP group members attend meetings, made useful contributions and reasonably live up to their responsibility by paying their dues. 
Tables 5: Contribution of variable in regression equation to group viability

\begin{tabular}{|c|c|c|c|c|c|}
\hline \multirow[t]{2}{*}{ Variables } & \multicolumn{2}{|c|}{$\begin{array}{l}\text { Unstandardised coeffi- } \\
\text { cient }\end{array}$} & \multirow{2}{*}{$\begin{array}{c}\begin{array}{c}\text { Standardized } \\
\text { Co-efficient }\end{array} \\
\text { Beta }\end{array}$} & \multirow[t]{2}{*}{$\mathbf{T}$} & \multirow[t]{2}{*}{ Sig } \\
\hline & B value & Std error & & & \\
\hline Constant & 8.265 & 2.119 & - & 3.900 & .000 \\
\hline Age & 2.540 & 0.873 & 0.181 & 2.909 & 0.172 \\
\hline Sex & -0.303 & 0.411 & -0.051 & -0.737 & 0.463 \\
\hline Marital Status & -0.420 & 0.608 & -0.051 & -0.691 & 0.491 \\
\hline Education attainment & -0.997 & 0.525 & -0.172 & -1.899 & 0.060 \\
\hline Household size & 0.206 & 0.098 & 3.142 & 2.100 & 0.038 \\
\hline Year of formal education & 0.027 & 0.052 & 0.048 & 0.508 & 0.613 \\
\hline Duration of membership in group & -0.160 & 0.085 & -0.134 & -1.891 & 0.062 \\
\hline Amount made from personal processing per month & $\begin{array}{l}2.27 \mathrm{E} \\
0.005\end{array}$ & 0.000 & 0.086 & 0.518 & 0.606 \\
\hline Extent of participation in group activities & 0.130 & 0.067 & 0.163 & 1.935 & 0.056 \\
\hline Frequency of participation in group activities & 0.242 & 0.092 & 0.237 & 2.640 & 0.010 \\
\hline Constraints & -0.125 & 0.026 & -0.342 & -4.722 & 0.000 \\
\hline
\end{tabular}

Furthermore, up to four members out of every five members frequently participated in group activities ranging from group processing activities, payment of dues and capacity building workshop attendance. They were however severely constrained by high cost of transportation and raw materials for processing, inadequate finance and poor market linkage. Members agreed that total compliance was achieved in record keeping and meeting attendance. Group viability was predicted by respondents' household size, frequency of participation in group activities and constraints they encountered in participation in group activities. In the light of the findings of this study, it is recommended that;

- Road infrastructures should be built for ease of market access

- Input supply as well as soft loans to members of the group will further enhance group viability.

- Capacity building on group cohesion is needed to further strengthen the group and consequently group viability

\section{REFERENCES}

Afolani CA and Ajani OI 1995 Gender participation, group formation and adoption of Cassava processing technolo- gies in Ogun State. In: the proceedings of the $8^{\text {th }}$ Annual Conference of the Nigeian Rural Sociological Association (NRSA) held at Ogun State, Ago Iwoye. $13^{\text {th }}-17^{\text {th }}$ March, 1994.pp 88-96.

Chamala S and Shingi PM 1997 Establishing and strengthening farmer organizations in improving agricultural extension; A Reference Manual. Swanson, BE, Bentz. RP and Sofranko, AI (eds) Food and Agriculture Organization of the United nations Rome. pp $185-194$.

Conroy C 2003 New directions for Nigeria's basic agricultural services. A discussion paper for Basic Agricultural Service (BAS). Natural Resource Institute, University of Greenwich, United Kingdom,.1: 61

Dannson AC Ezedinma TR Wambuwa B Bashasha, Kristen J and Satorius K. 2004 Strengthening farm agri business linkages in Africa in Alexandra R. (eds.) FAO Report . Rome p 7.

Dipeolu AO Ayinde IA Adebayo, KO Sanni LO Wandschenider DM White JL Westby A 2003 Challenges facing the cassava processing industries in meeting urban food needs in Nigeria. Paper presented at the international working meeting. Improving Food System in 
sub-Saharan Africa: Responding to a changing environment (FOODAFRICA) held at the palais du congress, Yaounde, Cameroon between $5^{\text {th }}-9^{\text {th }}$ May, 2003.

Ekong EE 2007 An Introduction to Rural Sociology. Third Edition. Dove Educational publishers, Uyo Nigeria pp 121-135.

Food and Agriculture Organisation (FAO) 2001 Farmer innovation and new technology options for food production, income generation and combating desertification (99/2000) Progress report 2001 Nairobi, Kenya. Food and Agriculture Organization of the United Nations.

Ladele AA 1995 Dynamics of Agricultural Extension Service structure and policy: The need for Group Extension in Sustainable Agricultural Technology Transfers in Nigeria. pp 57 - 58, In: Issues and Priorities for Nigeria Agricultural Extension in the $21^{\text {st }}$ Century Afolayan SO and Akinbode IA (eds.). Proceedings of the inaugural conference of the Agricultural Extension Society of Nigeria (AESON) February 28 - March 4.

National Population Commission (NPC) 2007 The need for population census Federal Ministry of Women Affairs and Social Development. Han press $34 \mathrm{p}$.

Okoye GI and Ihimodu II 2004 Poverty alleviation of small scale farm holders. The role of participatory research and extension. ARMTI Faculty forum $\left(2^{\text {nd }}\right.$ September). $21 \mathrm{p}$.

Onyenweaku CE and Nwaru JC 2005 Application of stochastic frontier production function to the measurement of technical efficiency in food crop production in Imo State, Nigeria. Nigerian Agricultural Journal 36: 1-12.

Srivastava JNL 2007 Recommendation of working groups on agricultural extension for formulation of eleventh five year plan 2007 - 2012 Working Group on Agricultural Extension constituted by planning commission Government of India New Dellhi, pp 27-29 p 3 Retrieved on January 11, 2010 from planning commission. nic.in/aboutus/ committee/wrkgrpll.p/vgll-agrext.pdf.

Stringfellow R Coulster J Lucy T Mekone C and Hussam A 1997 Improving the access of small holders to agricultural services in sub-saharan African: Farmer Cooperation and the Role of the Donor Community. No. 2 June.

Sule AM, Ogunwale SA and Atala TK 2002 Factors affecting adoption of fishing innovation among fishing entrepreneurs in Jebba Lake Community. Journal of Agricultural Extension 6:48-60.

Root and Tuber Expansion Programme (RTEP) 2010 Oyo state Root and Tuber Expansion Programme's Report 2010. p 57.

Zhang D and Flick WA 2001 Sticks, carrots and reforestation investment, land economics. 77(3): 443 - 456. 